medRxiv preprint doi: https://doi.org/10.1101/2021.05.26.21257879; this version posted May 30, 2021. The copyright holder for this preprint (which was not certified by peer review) is the author/funder, who has granted medRxiv a license to display the preprint in perpetuity.

It is made available under a CC-BY-NC-ND 4.0 International license .

\title{
Out-of-Pocket Spending for COVID-19 Hospitalizations in 2020
}

\author{
Kao-Ping Chua, MD, PhD ${ }^{\mathrm{a}, \mathrm{b}}$, Rena M. Conti, $\mathrm{PhD}^{\mathrm{c}}$, Nora V. Becker, MD, $\mathrm{PhD}^{\mathrm{d}}$
}

\section{Affiliations:}

${ }^{a}$ Department of Pediatrics, Susan B. Meister Child Health Evaluation and Research Center, University of Michigan Medical School, Ann Arbor

${ }^{b}$ Department of Health Management and Policy, University of Michigan School of Public Health, Ann Arbor

${ }^{c}$ Department of Markets, Public Policy, And Law, Institute for Health System Innovation and Policy, Questrom School of Business, Boston University, Boston

${ }^{\mathrm{d}}$ Division of General Medicine, Department of Internal Medicine, University of Michigan Medical School, Ann Arbor

Address correspondence to: Kao-Ping Chua, MD, PhD, 300 North Ingalls St, SPC 5456, Room 6E18, Ann Arbor, Michigan 48109-5456. E-mail: chuak@ med.umich.edu. Phone: 734-6158169

Date: May 26, 2021

Word count: 2990 
28 Question: How much were patients billed for COVID-19 hospitalizations in 2020?

Findings: Of 1,377 and 2,698 COVID-19 hospitalizations for privately insured and Medicare Advantage patients, $71.2 \%$ and $49.1 \%$ had cost-sharing for facility services billed by hospitals, services billed by clinicians or ancillary providers, or both. Among these hospitalizations, mean out-of-pocket spending was $\$ 788$ and $\$ 277.4 .6 \%$ and $1.3 \%$ had cost-sharing for facility services; among these hospitalizations, mean out-of-pocket spending was $\$ 3,840$ and $\$ 1,536$.

Meaning: Insurer cost-sharing waivers for COVID-19 hospitalizations may not cover all

37 hospitalization-related care. Patient out-of-pocket burden could be substantial if insurers allow 38 waivers to expire. 
medRxiv preprint doi: https://doi.org/10.1101/2021.05.26.21257879; this version posted May 30, 2021. The copyright holder for this preprint (which was not certified by peer review) is the author/funder, who has granted medRxiv a license to display the preprint in perpetuity.

It is made available under a CC-BY-NC-ND 4.0 International license .

\begin{abstract}
IMPORTANCE: Many insurers waived cost-sharing for COVID-19 hospitalizations during 2020. Nonetheless, patients may have been billed if their plans did not implement waivers or if waivers did not capture all hospitalization-related care, including clinician services. Assessing out-of-pocket spending for COVID-19 hospitalizations in 2020 could demonstrate the financial burden patients may face if insurers allow waivers to expire, as many chose to do during early 2021.
\end{abstract}

OBJECTIVE: To estimate out-of-pocket spending for COVID-19 hospitalizations in 2020

\title{
DESIGN: Cross-sectional analysis
}

SETTING: IQVIA PharMetrics® Plus for Academics Database, a national claims database

PARTICIPANTS: COVID-19 hospitalizations for privately insured and Medicare Advantage patients during March-September 2020

MAIN OUTCOMES/MEASURES: Mean total out-of-pocket spending, defined as the sum of out-of-pocket spending for facility services billed by hospitals (e.g., accommodation charges) and for professional/ancillary services billed by clinicians and ancillary providers (e.g., clinician inpatient evaluation and management, ambulance transport)

RESULTS: Analyses included 4,075 hospitalizations. Of the 1,377 hospitalizations for privately insured patients and the 2,698 hospitalizations for Medicare Advantage patients, 981 (71.2\%) and $1,324(49.1 \%)$ had out-of-pocket spending for facility services, professional/ancillary services, or both. Among these hospitalizations, mean (SD) total out-of-pocket spending was \$788 $(1,411)$ and \$277 (363). In contrast, 63 (4.6\%) and $36(1.3 \%)$ hospitalizations had out-ofpocket spending for facility services. Among these hospitalizations, mean total out-of-pocket spending was $\$ 3,840(3,186)$ and $\$ 1,536(1,402)$. Total out-of-pocket spending exceeded $\$ 4,000$ for $2.5 \%$ of privately insured hospitalizations, compared with $0.2 \%$ of Medicare Advantage hospitalizations.

CONCLUSIONS: Few COVID-19 hospitalizations in this study had out-of-pocket spending for facility services, suggesting most were covered by insurers with cost-sharing waivers. However, many hospitalizations had out-of-pocket spending for professional/ancillary services. Overall, 7 in 10 privately insured hospitalizations and half of Medicare Advantage hospitalizations had any out-of-pocket spending. Findings suggest insurer cost-sharing waivers may not cover all hospitalization-related care. Moreover, high cost-sharing for some hospitalizations suggests outof-pocket burden could be substantial if waivers expire, particularly for privately insured patients. Rather than rely on voluntary insurer actions to mitigate this burden, federal policymakers should consider mandating insurers to waive cost-sharing for all COVID-19 hospitalization-related care throughout the pandemic. 
medRxiv preprint doi: https://doi.org/10.1101/2021.05.26.21257879; this version posted May 30, 2021. The copyright holder for this preprint (which was not certified by peer review) is the author/funder, who has granted medRxiv a license to display the preprint in perpetuity.

It is made available under a CC-BY-NC-ND 4.0 International license .

\section{INTRODUCTION}

Between August 2020 and April 2021, there were more than 2.1 million U.S.

hospitalizations for coronavirus disease 2019 (COVID-19). ${ }^{1}$ To mitigate patient financial burden,

81

82

83

84

85

86

87

88

many private insurers and Medicaid Advantage insurers voluntarily waived cost-sharing for COVID-19 hospitalizations during part or all of $2020 .{ }^{2,3}$ Literature examining cost-sharing for other respiratory infection hospitalizations suggests these waivers potentially resulted in substantial savings for patients. ${ }^{4-6}$ For example, among privately insured patients hospitalized for respiratory infections between 2016-2019, average out-of-pocket spending was $\$ 1,653$ for patients in traditional plans and \$1,961 for patients in consumer-driven health plans. ${ }^{4}$ Among Medicare Advantage patients hospitalized for influenza in 2018, average out-of-pocket spending was almost $\$ 1,000 .^{6}$

While waivers may have mitigated financial burden for many patients hospitalized for COVID-19 during 2020, some patients may still have been billed if their plans did not implement waivers or if waivers did not capture all hospitalization-related care. Hospitalizations can result in two categories of bills. ${ }^{7,8}$ The first includes facility services provided by hospitals, such as accommodation and inpatient pharmacy services. The second includes services from clinicians and ancillary providers (hereafter referred to as "professional/ancillary services"). This category includes clinician services for emergency department and inpatient care, as well as ambulance services for transport to the hospital. While waivers would ideally cover both categories, some may only have covered facility services billed by hospitals, not professional/ancillary services billed separately by providers.

Protecting patients from the costs of COVID-19 hospitalizations is an important policy goal, as hospitalization surges may still occur despite vaccination efforts. Despite this, no study 
medRxiv preprint doi: https://doi.org/10.1101/2021.05.26.21257879; this version posted May 30, 2021. The copyright holder for this preprint (which was not certified by peer review) is the author/funder, who has granted medRxiv a license to display the preprint in perpetuity.

It is made available under a CC-BY-NC-ND 4.0 International license.

to our knowledge has assessed the amount patients were billed for COVID-19 hospitalizations during 2020, either overall or by service category. Addressing this knowledge gap may inform policy in several ways. First, it could motivate efforts to improve the comprehensiveness and implementation of existing insurer cost-sharing waivers for COVID-19 hospitalizations. Second, it could demonstrate the potential financial burden patients may face if insurers allow costsharing waivers to expire, as many chose to do during early $2021 .{ }^{9,10}$ Finally, it could illustrate the potential need for federal legislation mandating U.S. insurers to waive cost-sharing for these hospitalizations - legislation that was proposed, but not passed, in the U.S. House of Representatives in $2020 .{ }^{11}$ In this study, we used national claims data to estimate out-of-pocket spending for COVID-19 hospitalizations during March-September 2020 among patients covered by private and Medicare Advantage plans.

\section{METHODS}

Data source. In May 2021, we conducted a cross-sectional analysis of the IQVIA

PharMetrics ${ }^{\circledR}$ Plus for Academics database. This database contains fully-adjudicated medical and pharmacy claims from de-identified patients in all 50 states and the District of Columbia. Claims were complete through September 30, 2020 when data were delivered at the end of March 2021, corresponding to a six-month claims run-off period. The database included 1.0 million patients covered by Medicare Advantage plans and 7.7 million patients covered by fully-insured private plans in 2020. The database did not include any patients covered by self-insured private plans. Data include patient year of birth, state and region of residence, payer type, and plan type. Data also include International Classification of Diseases, Tenth Revision, Clinical Modification (ICD-10-CM) diagnosis codes, a hospitalization identifier assigned to all claims 
medRxiv preprint doi: https://doi.org/10.1101/2021.05.26.21257879; this version posted May 30, 2021. The copyright holder for this preprint (which was not certified by peer review) is the author/funder, who has granted medRxiv a license to display the preprint in perpetuity.

It is made available under a CC-BY-NC-ND 4.0 International license.

124 that occurred on or between the admission and discharge dates of hospitalizations, amounts

125 billed to patients (deductibles, co-insurance, and co-payments), and a flag for whether the billing

126 provider was a hospital, clinician, or other entity. The database does not include information on

127 race, ethnicity, household income, out-of-network status, or in-hospital death (to protect patient

128 confidentiality). Moreover, the database does not include plan identifiers or information on plan

129 benefit design, including whether insurers had cost-sharing waivers for COVID-19

130 hospitalizations. As discussed below, we conducted analyses to evaluate whether such waivers

131 may have been in place. Because data were de-identified, the Institutional Review Board of the

132 University of Michigan Medical School exempted analyses from human subjects review.

Study sample. We included hospitalizations that had a primary diagnosis of confirmed

134 COVID-19 infection (ICD-10-CM diagnosis code U071) and that began and ended between

135 March 1-September 29, 2020. We required discharge before September 30, 2020 to ensure the

136 end of hospitalizations was observed (see Appendix 1 for details). We excluded hospitalizations

137 if they were covered by a secondary insurer (e.g., a different private insurance plan) or if any

138 associated claim had missing data for out-of-pocket spending or billing provider type.

Categorization of claims. For each hospitalization, we assigned claims with the

141 for details):

142 1) Claims for facility services (institutional claims with a hospital or emergency department

143 place of service and a hospital billing provider type). These services included but were not

144 limited to hospital accommodation, facility charges for emergency department visits, and

145 inpatient laboratory, pharmacy, and radiology services.

146 2) Claims for professional/ancillary services, defined as one of three types of services: 
medRxiv preprint doi: https://doi.org/10.1101/2021.05.26.21257879; this version posted May 30, 2021. The copyright holder for this preprint (which was not certified by peer review) is the author/funder, who has granted medRxiv a license to display the preprint in perpetuity.

It is made available under a CC-BY-NC-ND 4.0 International license .

- Ambulance (claims with an ambulance place of service or procedure code)

- Clinician (claims with an emergency department or hospital place of service and clinician billing provider type)

- Miscellaneous (claims with billing provider type for miscellaneous providers, such as durable medical equipment providers and dialysis centers).

For additional context, clinician services were divided into 4 subtypes:

- Emergency department (claims with an emergency department place of service)

- Inpatient evaluation and management (claims with a hospital place of service and procedure code for evaluation and management, e.g., initial or subsequent hospital care)

- Inpatient diagnostic testing (claims with hospital place of service and procedure codes for laboratory tests, radiology tests, electrocardiograms, echocardiography, electroencephalograms, and vascular diagnostic studies)

- Other inpatient services (claims with hospital place of service and procedure codes for services other than evaluation and management and diagnostic testing, such as procedures).

3) Unclassified claims. This category included the approximately $4.3 \%$ of claims that were assigned the confinement identifier for the COVID-19 hospitalization but did not meet criteria for a facility or professional/ancillary service. Three-quarters of these claims had a place of service code for office, home, or hospital outpatient department. While some of these claims could represent care at visits resulting in direct admission to the hospital, they could also include care provided at unrelated visits. In the main analysis, we excluded these claims to maximize the probability of only capturing out-of-pocket spending for services truly associated with hospitalizations. We included these claims in a sensitivity analysis. 
medRxiv preprint doi: https://doi.org/10.1101/2021.05.26.21257879; this version posted May 30, 2021. The copyright holder for this preprint (which was not certified by peer review) is the author/funder, who has granted medRxiv a license to display the preprint in perpetuity.

It is made available under a CC-BY-NC-ND 4.0 International license .

Outcomes. Out-of-pocket spending was defined as the sum of deductibles, co-insurance,

171

172

173

174

175

176

177

178

179

and co-payments. For each payer type (private insurance and Medicare Advantage), we determined the proportion of hospitalizations in two categories: those with out-of-pocket spending for facility services (with or without out-of-pocket spending for professional/ancillary services), and those with out-of-pocket spending for facility services, professional/ancillary services, or both. For hospitalizations in both categories, we calculated total out-of-pocket spending, defined as the sum of out-of-pocket spending across facility and professional/ancillary services. Additionally, we calculated the proportion of all hospitalizations with out-of-pocket spending for the 3 main types of professional/ancillary services and for the 4 subtypes of clinician services.

Presence of cost-sharing waivers. The database did not report whether COVID-19 hospitalizations were covered by plans with cost-sharing waivers. However, as noted below, the vast majority of hospitalizations in our sample did not have cost-sharing for facility services. While this might suggest that most hospitalizations were covered by insurers that waived costsharing for facility services - that is, that the absence of cost-sharing for facility services implied the presence of a waiver - a potential alternative explanation is that most patients had already met their plan's annual out-of-pocket maximum at the time of hospitalizations. To evaluate this possibility, we conducted a sensitivity analysis in which we restricted analyses to hospitalizations by patients continuously enrolled since January 2020, calculated out-of-pocket spending across medical and pharmacy claims in 2020 prior to the hospitalization, and calculated the incidence of out-of-pocket spending for facility services among hospitalizations for patients in the lowest quartile of this prior out-of-pocket spending. These patients likely had not met outof-pocket maximums at the time of hospitalizations. If few of these patients had cost-sharing for 
medRxiv preprint doi: https://doi.org/10.1101/2021.05.26.21257879; this version posted May 30, 2021. The copyright holder for this preprint (which was not certified by peer review) is the author/funder, who has granted medRxiv a license to display the preprint in perpetuity.

It is made available under a CC-BY-NC-ND 4.0 International license .

193 facility services, that would support the notion that cost-sharing waivers, rather than meeting out-

194 of-pocket maximums, drove the low observed incidence of cost-sharing for facility services.

We also explored whether it was reasonable to assume that hospitalizations with out-of-

196 pocket spending for facility services were not covered by insurers with cost-sharing waivers for

197 these services (i.e., that the presence of cost-sharing for facility services implied the absence of a

198 waiver - the inverse of the assumption above). To evaluate this assumption, we compared the

199 incidence of out-of-pocket spending for facility services between COVID-19 hospitalizations and

200 influenza hospitalizations. The latter require similar care as COVID-19 hospitalizations, but no

201 insurers to our knowledge waived cost-sharing for influenza hospitalizations during the study

202 period. If the presence of out-of-pocket spending for facility services implies the absence of a

203 waiver for these services, a much higher proportion of influenza hospitalizations would have out-

204 of-pocket spending for facility services compared with COVID-19 hospitalizations. In this

205 analysis, influenza hospitalizations were those that met similar inclusion and exclusion criterion

206 but had a primary diagnosis of influenza (ICD-10-CM diagnosis code J09-J11). No influenza

207 hospitalizations included also had a COVID-19 diagnosis code (U017).

208 Statistical analysis. We used descriptive statistics to assess patient characteristics, length

209 of stay, and intensive care unit utilization (based on revenue codes corresponding to

210 accommodation charges for intensive care or coronary care units; Appendix 2). To contextualize

211 cost-sharing amounts, we calculated mean and median allowed amounts (reimbursement to

212 providers plus patient liability) across facility and professional/ancillary services among

213 privately insured and Medicare Advantage hospitalizations separately. Analyses used SAS 9.4

214 (SAS Institute). 
medRxiv preprint doi: https://doi.org/10.1101/2021.05.26.21257879; this version posted May 30, 2021. The copyright holder for this preprint (which was not certified by peer review) is the author/funder, who has granted medRxiv a license to display the preprint in perpetuity.

It is made available under a CC-BY-NC-ND 4.0 International license .

\section{RESULTS}

Sample characteristics. Of 4,371 COVID-19 hospitalizations meeting inclusion criteria, 230 were excluded because the insurer was secondary, 63 because data on billing provider type were missing, and 3 because out-of-pocket spending data were missing. Overall, 296 (6.8\%) hospitalizations were excluded, leaving 4,075 hospitalizations. These hospitalizations occurred among 3,875 unique patients; 282 patients had 2 hospitalizations, while 9 patients had 3 hospitalizations.

Table 1 displays characteristics of the 4,075 hospitalizations. Overall, 1,377 (33.8\%) and 2,698 (66.2\%) hospitalizations were for privately insured and Medicare Advantage patients. Of the former, $552(40.1 \%)$ were for female patients. Mean length of stay was 7.3 (SD 7.6) days; $640(46.5 \%)$ hospitalizations involved intensive care unit utilization. Of 2,698 hospitalizations for Medicare Advantage patients, 1,432 (53.1\%) were for females. Mean length of stay was 9.2 days (SD 8.9); 1,212 (44.9\%) hospitalizations involved intensive care unit utilization.

Privately insured hospitalizations were most commonly covered by preferred provider organization plans (47.0\%). Mean and median allowed amounts for privately insured hospitalizations was $\$ 42,200$ (SD 65,328) and $\$ 25,339\left(25^{\text {th }}-75^{\text {th }}\right.$ percentile: $\left.\$ 16,064-\$ 39,484\right)$. Medicare Advantage hospitalizations were most commonly covered by health maintenance organization plans (80.1\%). Mean and median allowed amounts for Medicare Advantage hospitalizations were $\$ 21,501$ (SD 21,387$)$ and $\$ 17,480\left(25^{\text {th }}-75^{\text {th }}\right.$ percentile: $\left.\$ 14,383-\$ 21,133\right)$. Out-of-pocket spending. Of the 1,377 and 2,698 hospitalizations for privately insured and Medicare Advantage patients, 63 (4.6\%) and 36 (1.3\%) had out-of-pocket spending for facility services. Among these 63 and 36 hospitalizations, mean (SD) total out-of-pocket spending was $\$ 3,840(3,186)$ and $\$ 1,536(1,402)$. In contrast, of the 1,377 and 2,698 hospitalizations for 
medRxiv preprint doi: https://doi.org/10.1101/2021.05.26.21257879; this version posted May 30, 2021. The copyright holder for this preprint (which was not certified by peer review) is the author/funder, who has granted medRxiv a license to display the preprint in perpetuity.

It is made available under a CC-BY-NC-ND 4.0 International license .

privately insured and Medicare Advantage patients, 981 (71.2\%) and 1,324 (49.1\%) had out-ofpocket spending for facility services, professional/ancillary services, or both. Among these 981 and 1,324 hospitalizations, mean total out-of-pocket spending was \$788 (1,411) and \$277 (363) (Table 2). Of all 1,377 privately insured hospitalizations, $99(7.2 \%)$ and $34(2.5 \%)$ had total outof-pocket exceeding \$2,000 and \$4,000. Of all 2,698 hospitalizations for Medicare Advantage patients, the corresponding numbers were $7(0.3 \%)$ and $5(0.2 \%)$.

Table 3 shows the incidence and magnitude of out-of-pocket spending for each of the 3 main types of professional/ancillary services and for the 4 subtypes of clinician services. Of the 1,377 hospitalizations for privately insured patients, $137(9.9 \%)$ and $918(66.7 \%)$ had out-ofpocket spending for ambulance services and clinician services. When analyzing clinician services by subtype, $516(37.5 \%)$ and 641 (46.6\%) hospitalizations had out-of-pocket spending for inpatient evaluation and management services and diagnostic testing services. Among the 516 hospitalizations with out-of-pocket spending for inpatient evaluation and management services, mean (SD) out-of-pocket spending for these services was \$622 (765). Compared with hospitalizations for privately insured patients, hospitalizations for Medicare Advantage patients had a higher incidence of out-of-pocket spending for ambulance services (36.5\%) but a lower incidence for clinician services $(22.1 \%)$.

Analyses assessing presence of cost-sharing waivers. Among hospitalizations for privately insured and Medicare Advantage patients in the lowest quartile of out-of-pocket spending prior to hospitalization, the proportion with out-of-pocket spending for facility services was still modest, at 8.3\% and 1.8\% (Appendix 3). A total of 61 and 178 influenza hospitalizations for privately insured and Medicare Advantage patients met inclusion and exclusion criterion. Of these hospitalizations, 51 (83.6\%) and $159(89.3 \%)$ had out-of-pocket 
medRxiv preprint doi: https://doi.org/10.1101/2021.05.26.21257879; this version posted May 30, 2021. The copyright holder for this preprint (which was not certified by peer review) is the author/funder, who has granted medRxiv a license to display the preprint in perpetuity.

It is made available under a CC-BY-NC-ND 4.0 International license .

262

263

264

265

266

267

268

269

270

271

272

273

274

275

276

277

278

279

280

281

282

283

284

spending for facility services, compared with $4.6 \%$ and $1.3 \%$ among COVID-19 hospitalizations covered by private insurance and Medicare Advantage plans (Table 2).

Sensitivity analysis including unclassified claims. When including the $4.3 \%$ of claims that did not meet criteria for a facility or professional/ancillary service, the proportion of hospitalizations for privately insured and Medicare Advantage patients with out-of-pocket spending for any associated claim was $73.6 \%$ and $53.8 \%$. These proportions were similar to the proportion of hospitalizations with out-of-pocket spending for facility services, professional/ancillary services, or both $(71.2 \%$ and $49.1 \%)$.

\section{DISCUSSION}

In this national study of COVID-19 hospitalizations between March-September 2020, the incidence of out-of-pocket spending differed substantially for facility and professional/ancillary services. When considering facility services only, few COVID-19 hospitalizations had out-ofpocket spending. However, when also considering professional/ancillary services, 7 in 10 privately insured hospitalizations and half of Medicare Advantage hospitalizations had any outof-pocket spending. If the absence of out-of-pocket spending for facility services is an indicator of the presence of an insurer cost-sharing waiver for these services - an assumption supported by our analyses - then most study hospitalizations were covered by insurers that at least waived cost-sharing for facility services. If true, then the high incidence of out-of-pocket spending for professional/ancillary services suggests that many insurer cost-sharing waivers may fail to capture all hospitalization-related care.

Whether this failure is intentional is unclear. Unlike COVID-19 testing and vaccination, there is no federal mandate for insurers to waive cost-sharing for COVID-19 hospitalizations. ${ }^{12}$ 
medRxiv preprint doi: https://doi.org/10.1101/2021.05.26.21257879; this version posted May 30, 2021. The copyright holder for this preprint (which was not certified by peer review) is the author/funder, who has granted medRxiv a license to display the preprint in perpetuity.

It is made available under a CC-BY-NC-ND 4.0 International license .

285 Consequently, insurer waivers could be heterogeneous, with some applying only to facility services and others applying to hospitalization care more broadly. Even if insurers intend for waivers to capture all hospitalization-related care, implementation problems may occur. For example, if insurers do not link clinician inpatient evaluation and management bills to the COVID-19 hospitalization, patients may be billed erroneously. professional/ancillary services related to COVID-19 hospitalizations. First, insurers with no costsharing waiver or with waivers of limited scope could consider implementing a comprehensive waiver, for example one that covers all services on or between the admission and discharge dates of hospitalizations. Second, insurers that already have comprehensive waivers could work to ensure appropriate implementation. Finally, clinicians could encourage patients to contest any bills for professional/ancillary services that should be covered under an insurer's cost-sharing 297 waiver. hospitalizations, mean total out-of-pocket spending was $\$ 3,840$ and $\$ 1,536$, respectively. If the presence of out-of-pocket spending for facility services implies the absence of an insurer cost-

302 sharing waiver for these services - as suggested by the fact that the vast majority of influenza 303 hospitalizations had cost-sharing for facility services - our findings suggest that out-of-pocket 304 burden for COVID-19 hospitalizations could be large without insurer cost-sharing waivers. This 305 would have important policy implications. In early 2021, several large insurers, including 306 Anthem and United Healthcare, allowed their cost-sharing waivers for COVID-19 
medRxiv preprint doi: https://doi.org/10.1101/2021.05.26.21257879; this version posted May 30, 2021. The copyright holder for this preprint (which was not certified by peer review) is the author/funder, who has granted medRxiv a license to display the preprint in perpetuity. It is made available under a CC-BY-NC-ND 4.0 International license .

307 hospitalizations to expire. ${ }^{9,10}$ Analyses suggest patients covered by these insurers could now face 308 substantial financial burden for COVID-19 hospitalizations, particularly the privately insured.

A strength of this study its use of national, fully-adjudicated claims data. Such data are typically considered complete after a six-month time lag, meaning claims through the latter part of 2020 only became available shortly before the time of writing in May 2021. An additional

312 strength is the inclusion of both privately insured and Medicare Advantage plans. These plans 313 are important sources of coverage for older adults and the elderly, ${ }^{13,14}$ two age groups accounting

314 for high shares of COVID-19 hospitalizations. ${ }^{15}$

This study also has limitations. First, despite strong indirect evidence, we cannot prove that COVID-19 hospitalizations in this study were mostly covered by plans with cost-sharing

317 waivers. Second, if patients did not pay the amounts they were billed, the incidence of actual out318 of-pocket spending would differ from the incidence estimated by this study. However, the 319 amount billed to patients still illustrates the financial burden patients may face without cost320 sharing waivers. Third, COVID-19 hospitalizations without the diagnosis code for confirmed 321 COVID-19 (U017) were not included. However, hospitals rapidly started using this code during the first half of $2020 .{ }^{16}$ Finally, our database is not necessarily representative of all private and

323 Medicare Advantage plans. However, most privately insured hospitalizations in our study were

324 covered by preferred private organization plans, while most Medicare Advantage

325 hospitalizations were covered by health maintenance organizations, consistent with the national 326 distribution of plan type among privately insured and Medicare Advantage enrollees. ${ }^{13,17}$ 


\section{CONCLUSION}

Findings suggest that insurer cost-sharing waivers for COVID-19 hospitalizations may

332 not always capture all hospitalization-related care. Moreover, patient financial burden for

333 COVID-19 hospitalizations could be substantial without insurer waivers. The growing trend

334 towards abandonment of these waivers suggests that relying on voluntary insurer actions is not

335 an ideal policy strategy to protect patients from the costs of COVID-19 hospitalizations. ${ }^{9,10}$ To

336 achieve this goal, federal policymakers might consider legislation mandating insurers to waive

337 cost-sharing for COVID-19 hospitalizations throughout the public health emergency. ${ }^{11}$ Such a

338 mandate would ideally include all hospitalization-related care, similar to existing federal

339 mandates which require insurers to fully cover all direct and related costs of COVID-19 tests and

340 vaccines. ${ }^{12}$ Future research should continue to examine patient financial burden of COVID-19

341 hospitalizations as coverage policies change. 


\section{ACKNOWLEDGEMENTS}

344 Author Contributions: Dr. Chua had full access to all of the data in the study and takes

345 responsibility for the integrity of the data and the accuracy of the data analysis.

347 Study concept and design: Chua, Conti, Becker

348 Acquisition of data: Chua

349 Analysis and interpretation of data: Chua, Conti, Becker

350 Drafting of the manuscript: Chua

351 Critical revision of the manuscript: Chua, Conti, Becker

352 Statistical analysis: Chua

353 Study supervision: Becker

Funding source: Funding for purchasing IQVIA data was partially provided by the Susan B. Meister Child Health Evaluation and Research Center at the University of Michigan Medical School. Dr. Chua's effort is supported by a career development award from the National Institute on Drug Abuse (grant number 1K08DA048110-01). The funders played no role in the design and conduct of the study; collection, management, analysis, and interpretation of the data; preparation, review, or approval of the manuscript; and decision to submit the manuscript for 361 publication. 
medRxiv preprint doi: https://doi.org/10.1101/2021.05.26.21257879; this version posted May 30, 2021. The copyright holder for this preprint (which was not certified by peer review) is the author/funder, who has granted medRxiv a license to display the preprint in perpetuity.

It is made available under a CC-BY-NC-ND 4.0 International license .

401

402

403

404

405

406

407

408

409

410

\section{REFERENCES}

1. Centers for Disease Control and Prevention. COVID Data Tracker. 2021; https://covid.cdc.gov/covid-data-tracker/\#new-hospital-admissions. Accessed May 25, 2021.

2. America's Health Insurance Plans. Health insurance providers respond to coronavirus (COVID-19). 2020; https://www.ahip.org/health-insurance-providers-respond-tocoronavirus-covid-19. Accessed May 25, 2021.

3. McDermott D, Cox C. Cost-Sharing Waivers and Premium Relief by Private Plans in Response to COVID-19 (Nov. 2020 Update). 2020; https://www.kff.org/healthcosts/issue-brief/cost-sharing-waivers-and-premium-relief-by-private-plans-in-responseto-covid-19/. Accessed April 30, 2021.

4. Eisenberg MD, Barry CL, Schilling CL, Kennedy-Hendricks A. Financial Risk for COVID-19-like Respiratory Hospitalizations in Consumer-Directed Health Plans. Am J Prev Med. 2020;59(3):445-448.

5. Rae M, Claxton G, Kurani N, McDermott D, Cox C. Potential costs of coronavirus treatment for people with employer coverage. 2020; https://www.healthsystemtracker.org/brief/potential-costs-of-coronavirus-treatment-forpeople-with-employer-coverage/. Accessed March 17, 2020.

6. Chua KP, Conti RM. Out-of-Pocket Spending for Influenza Hospitalizations in Medicare Advantage. Am J Prev Med. 2021;60(4):537-541.

7. Cooper Z, Nguyen H, Shekita N, Morton FS. Out-Of-Network Billing And Negotiated Payments For Hospital-Based Physicians. Health Aff (Millwood). 2020;39(1):24-32.

8. Cooper Z, Scott Morton F. Out-of-Network Emergency-Physician Bills - An Unwelcome Surprise. N Engl J Med. 2016;375(20):1915-1918.

9. Blue Cross Blue Shield of North Carolina. Updates on COVID-19 Provider and Member Support Measures. 2021; https://www.bluecrossnc.com/provider-news/updates-covid-19provider-and-member-support-measures-4. Accessed April 19, 2021.

10. Appleby J. Time to Say Goodbye to Some Insurers' Waivers for Covid Treatment Fees. Kasier Health News. April 29, 2021.

11. The Heroes Act, H.R. 6800 (2020).

12. Coronavirus Aid, Relief, and Economic Security Act, Pub. L. No. 116-136 (2020).

13. Kaiser Family Foundation. A dozen facts about Medicare Advantage in 2019. 2019; https://www.kff.org/medicare/issue-brief/a-dozen-facts-about-medicare-advantage-in2019. Accessed July 8, 2020.

14. Kaiser Family Foundation. Health Insurance Coverage of Non-Elderly 0-64. [Internet]. 2019; https://www.kff.org/other/state-indicator/nonelderly-064/?dataView=1\&currentTimeframe=0\&sortModel=\%7B \%22 colId\%22:\%22Location $\% 2$ 2,\%22sort\%22:\%22asc\%22\%7D. Accessed May 1, 2021.

15. Centers for Disease Control and Prevention. COVID-NET Laboratory-confirmed COVID-19 hospitalizations. 2021; https://covid.cdc.gov/covid-data-tracker/\#covidnethospitalization-network. Accessed May 1, 2021.

16. Kadri SS, Gundrum J, Warner S, et al. Uptake and Accuracy of the Diagnosis Code for COVID-19 Among US Hospitalizations. JAMA. 2020;324(24):2553-2554.

17. Kaiser Family Foundation. Employer health benefits: 2020 annual survey. Kaiser Family Foundation; 2020. 
Table 1. Characteristics of COVID-19 hospitalizations between March-September 2020, IQVIA PharmMetrics Plus for Academics

\section{Number of COVID-19 hospitalizations}

\section{Month of admission}

March

April

May

June

July

August

September

Mean length of stay (SD)

Any intensive care unit use ${ }^{a}$

\section{Age in years}

$0-17$

18-25

26-34

$35-44$

45-54

55-64

$65-74$

$75-85$

$>85$

Sex

Male

Female

Region

Northeast

Midwest

South

West

\section{Plan type}

Health maintenance organization

Preferred provider organization

Consumer-directed health plan

Unknown

\section{Private insurance}

1,377

$106(7.7 \%)$

$307(22.3 \%)$

$120(8.7 \%)$

$147(10.7 \%)$

$352(25.6 \%)$

$204(14.8 \%)$

$141(10.2 \%)$

$7.3(7.6)$

$640(46.5 \%)$

$$
12(0.9 \%)
$$

$19(1.4 \%)$

$75(5.4 \%)$

$201(14.6 \%)$

$389(28.2 \%)$

$550(39.9 \%)$

$107(7.8 \%)$

$21(1.5 \%)$

$3(0.2 \%)$

$825(59.9 \%)$

$552(40.1 \%)$

$200(14.5 \%)$

$315(22.9 \%)$

$623(45.2 \%)$

$232(16.8 \%)$

$504(36.6 \%)$

$647(47.0 \%)$

$226(16.4 \%)$

$0(0.0 \%)$
Medicare Advantage

2,698

$236(8.7 \%)$

$917(34.0 \%)$

$331(12.3 \%)$

$200(7.4 \%)$

$413(15.3 \%)$

$392(14.5 \%)$

$209(7.7 \%)$

$9.2(8.9)$

$1,212(44.9 \%)$

\section{$0(0.0 \%)$}

$1(0.0 \%)$

$7(0.3 \%)$

$14(0.5 \%)$

$101(3.7 \%)$

$285(10.6 \%)$

$877(32.5 \%)$

$925(34.3 \%)$

$488(18.1 \%)$

$1,266(46.9 \%)$

$1,432(53.1 \%)$

$917(34.0 \%)$

$1,062(39.4 \%)$

$433(16.0 \%)$

$274(10.2 \%)$

$2,161(80.1 \%)$

$512(19.0 \%)$

$0(0.0 \%)$

$25(0.9 \%)$

${ }^{a}$ Defined as the occurrence of $\geq 1$ claim with a revenue code for intensive care unit or coronary care unit (0200-0209, 0210-0219) 
Table 2. Incidence and magnitude of out-of-pocket spending among COVID-19 and influenza hospitalizations, IQVIA PharMetrics for Academics Database

\section{Hospitalization type}

\section{Private insurance, COVID-19 $(n=1,377)$}

Had OOP spending for facility services

Had OOP spending for facility services, professional/ancillary services, or both

\section{Medicare Advantage, COVID-19 $(n=2,698)$}

Had OOP spending for facility services

Had OOP spending for facility services, professional/ancillary services, or both

\section{Private insurance, influenza $(n=61)$}

Had OOP spending for facility services

Had OOP spending for facility services, professional/ancillary services, or both

\section{Medicare Advantage, influenza $(n=178)$}

Had OOP spending for facility services

Had OOP spending for facility services, professional/ancillary services, or both

\section{No. of \\ hospitalizations (\% \\ of total) \\ Mean (SD) total OOP spending}

\author{
$63(4.6 \%)$
}

$981(71.2 \%)$

\begin{abstract}
$\$ 3,840(3,186)$
\end{abstract}
$\$ 788(1,411)$

\author{
$36(1.3 \%)$
}

$1,324(49.1 \%)$

$\$ 1,536(1,402)$

$\$ 277$ (363)

$\begin{array}{lll}51(83.6 \%) & \$ 3,510(2,524) & \$ 2,998(2,293) \\ 55(90.2 \%) & \$ 3,327(2,528) & \$ 2,780(2,342)\end{array}$

$159(89.3 \%)$

$\$ 1,226$ (708)

$173(97.2 \%)$

$\$ 1,150$ (728)
$\$ 3,348(2,950)$

$\$ 215(1,107)$

$\$ 1,440(1,405)$

$\$ 39$ (327)

$\$ 1,117$ (665)

$\$ 1,027$ (707)

P

Mean (SD) OOP services $^{a}$

professiong

Mean (SD) OOP

spending:

services ${ }^{a}$

$\$ 492$ (849)

$\$ 573$ (869)

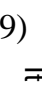

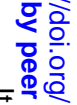

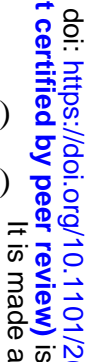

$\$ 97$ (147) $\$ 238(191)$ 离

$\$ 546$ (620)

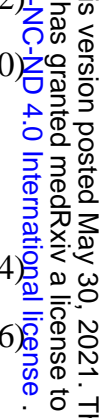

OOP - out-of-pocket

${ }^{a}$ See Appendix 2 for codes used to identify facility and professional/ancillary services. Facility services were those billed by hospitals for services such as accommodation. Professional/ancillary services were those billed by clinicians and ancillary providers, such as ambulance providers. 
Table 3. Incidence and magnitude of out-of-pocket spending for professional/ancillary services among COVID-19 hospitalizations, IQVIA PharMetrics for Academics Database

Privately insured ( $n=1,377$ hospitalizations)

Service type

Main types of

professional/ancillary

$\underline{\text { services }}^{\mathbf{a}}$

Ambulance

Clinician

Miscellaneous ${ }^{\mathrm{b}}$

\section{Subtypes of clinician services}

Emergency department

Inpatient evaluation and management

Inpatient diagnostic

Other inpatient ${ }^{\mathrm{c}}$

\begin{tabular}{|c|c|c|c|}
\hline $\begin{array}{c}\text { No. patients } \\
\text { with } \geq 1 \text { claim } \\
(\% \text { patients in } \\
\text { sample })\end{array}$ & $\begin{array}{l}\text { Mean (SD) } \\
\text { OOP } \\
\text { spending per } \\
\text { patient in } \\
\text { sample }\end{array}$ & $\begin{array}{l}\text { No. patients } \\
\text { with OOP } \\
\text { spending } \\
\text { (\% patients } \\
\text { in sample) }\end{array}$ & $\begin{array}{c}\text { Mean (SD) } \\
\text { OOP } \\
\text { spending } \\
\text { among } \\
\text { patients with } \\
\text { OOP } \\
\text { spending }\end{array}$ \\
\hline $305(22.1 \%)$ & $\$ 59$ (248) & $137(9.9 \%)$ & $\$ 596(550)$ \\
\hline $1,334(96.9 \%)$ & $\$ 317$ (682) & $918(66.7 \%)$ & $\$ 476$ (789) \\
\hline $272(19.8 \%)$ & $\$ 32$ (177) & $167(12.1 \%)$ & $\$ 263(445)$ \\
\hline $746(54.2 \%)$ & $\$ 31(103)$ & $399(29.0 \%)$ & $\$ 106$ (169) \\
\hline $1,234(89.6 \%)$ & $\$ 233$ (557) & $516(37.5 \%)$ & $\$ 622(765)$ \\
\hline $668(48.5 \%)$ & $\$ 36(85)$ & $641(46.6 \%)$ & $\$ 78(111)$ \\
\hline $109(7.9 \%)$ & $\$ 17(179)$ & $63(4.6 \%)$ & $\$ 375$ (757) \\
\hline
\end{tabular}

Medicare Advantage ( $n=2,698$ hospitalizations)

\begin{tabular}{|c|c|c|c|}
\hline $\begin{array}{c}\text { No. patients } \\
\text { with } \geq 1 \text { claim } \\
\text { (\% patients in } \\
\text { sample) }\end{array}$ & $\begin{array}{c}\text { Mean (SD) } \\
\text { OOP } \\
\text { spending per } \\
\text { patient in } \\
\text { sample }\end{array}$ & $\begin{array}{l}\text { No. patients } \\
\text { with OOP } \\
\text { spending } \\
\text { (\% patients } \\
\text { in sample) }\end{array}$ & $\begin{array}{c}\text { Mean (SD) } \\
\text { OOP } \\
\text { spending } \\
\text { among } \\
\text { patients with } \\
\text { OOP } \\
\text { spending }\end{array}$ \\
\hline $1,425(52.8 \%)$ & \$87 (139) & $985(36.5 \%)$ & $\$ 239$ (130) \\
\hline $2,608(96.7 \%)$ & $\$ 29$ (117) & $595(22.1 \%)$ & $\$ 130(221)$ \\
\hline $401(14.9 \%)$ & $\$ 1(10)$ & $99(3.7 \%)$ & $\$ 26(44)$ \\
\hline $1,493(55.3 \%)$ & $\$ 0(1)$ & $255(9.5 \%)$ & $\$ 2(2)$ \\
\hline $2,495(92.5 \%)$ & $\$ 24(103)$ & $394(14.6 \%)$ & $\$ 162(225)$ \\
\hline $1,438(53.3 \%)$ & $\$ 3(14)$ & $427(15.8 \%)$ & $\$ 18(32)$ \\
\hline $314(11.6 \%)$ & $\$ 2(19)$ & $83(3.1 \%)$ & $\$ 67$ (87) \\
\hline
\end{tabular}

OOP - out-of-pocket

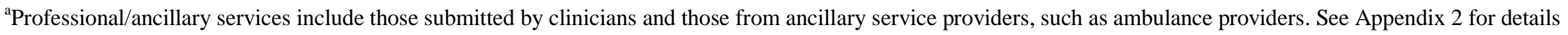

${ }^{\mathrm{b}}$ Services from miscellaneous providers, such as a durable medical equipment provider or dialysis center

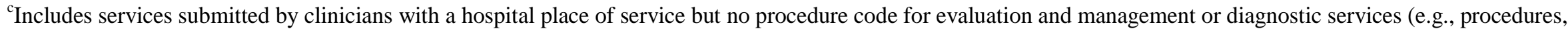
anesthesia) 